\title{
Protesa obturator definitif resin akrilik pada pasien systemic lupus erythematosus (SLE) pasca maksilektomi
}

\author{
Pramudya Aditama1, Erwan Sugiatno1, Murti Indrastuti', Endang Wahyuningtyas \\ 1Departemen Prostodonsia, Fakultas Kedokteran Gigi Universitas Gajdah Mada, Indonesia \\ *Korespondensi: pramudvaaditama@omail.com \\ Submisi: 19 Juni 2020; Penerimaan: 28 November 2020; Publikasi online: 30 November 2020 \\ DOI: $\underline{10.24198 / \mathrm{jkg} . \mathrm{v} 32 \mathrm{i} 2.28175}$
}

\begin{abstract}
ABSTRAK
Pendahuluan: Systemic lupus erythematosus (SLE) merupakan inflamasi kronis yang dapat melibatkan sistem saraf, membran mukosa, dan organ lain dalam tubuh. Avascular bone necrosis (AVN) merupakan gejala yang muncul pada penderita SLE. Maksilektomi dilakukan pada tulang maksila yang mengalami AVN. Penutupan celah pasca maksilektomi tersebut dilakukan dengan cara menggunakan protesa maksilofasial intraoral yaitu obturator. Tujuan laporan kasus ini mengkaji rehabilitasi prostetik menggunakan protesa obturator definitif resin akrilik pada penderita SLE pasca maksilektomi. Laporan kasus: Seorang wanita berusia 21 tahun datang ke Poli Gigi dan Mulut RSUP Dr. Sardjito dengan keluhan bau mulut, hilangnya gusi pada langit-langit, dan kegoyahan gigi rahang atas. Pasien didiagnosis SLE sejak lebih dari 1 tahun yang lalu. Pada pemeriksaan intraoral, selain lesi pada mukosa palatum, ditemukan juga nekrosis pada tulang palatum, kehilangan gigi 14, 15, 16, dan 25, serta kegoyahan derajat 3 pada seluruh gigi rahang atas yang tersisa. Pasien dirawat dengan obat Myfortic $(2 \times 180 \mathrm{mg} / \mathrm{hari})$ dan Fluconazole (1x150 mg/hari) kemudian dirujuk ke Poli Bedah Mulut untuk dilakukan maksilektomi, dilanjutkan dengan pembuatan protesa obturator oleh tim prostodonti. Pasien dibuatkan obturator pasca bedah untuk menutup celah palatum pasca maksilektomi. Pencetakan menggunakan bahan hydrocolloid irreversible sebelum operasi untuk pembuatan obturator pasca bedah. Insersi obturator menunjukkan celah palatum tertutup rapat oleh plat akrilik. Retensi didapatkan menggunakan kawat stainless pada titanium wire mesh pengganti tulang maksila. Tidak ada keluhan saat kontrol, penelanan baik. Tiga bulan pasca pemakaian obturator pasca bedah dilakukan pemasangan obturator definitif resin akrilik rahang atas. Pemeriksaan klinis menunjukkan suara sengau berkurang, estetis, dan pengunyahan baik. Simpulan: Protesa obturator definitif resin akrilik pada pasien SLE pasca maksilektomi dapat mengembalikan fungsi estetik, mengurangi suara sengau (mengembalikan fungsi bicara), mengembalikan fungsi penelanan, dan pengunyahan.
\end{abstract}

Kata kunci: Maksilektomi, obturator definitif resin akrilik, systemic lupus erythematosus.

\section{Acrylic resin definitive obturator prosthesis in systemic lupus erythematosus (SLE) patients post-maxillectomy}

\section{ABSTRACT}

Introduction: Systemic lupus erythematosus (SLE) is a chronic inflammation that involves the nervous system, mucous membranes, and other organs. Avascular bone necrosis (AVN) is a symptom that appears in people with SLE. Maxillectomy is performed on the maxillary bone affected with AVN. The postmaxillectomy gap closure was performed using an intraoral maxillofacial prosthesis, namely an obturator. This case report was aimed to examine the prosthetic rehabilitation using Acrylic resin definitive obturator prosthesis in SLE patients post-maxillectomy. Case report: A 21-years-old woman came to Dr Sardjito Oral Clinic with complaints of bad breath, palatogingival loss, and loose maxillary teeth. The patients was diagnosed with SLE for more than one year prior. The intraoral examination result showed that apart from the palatal mucosa lesions, there was also found necrosis of the palate bone, loss of teeth 14, 15, 16, and 25 , and grade 3 loose of all of the remaining maxillary teeth. The patient was treated with Myfortic ${ }^{\circledR}(2 x$ $180 \mathrm{mg} /$ day $)$ and Fluconazole $\AA(1 \times 150 \mathrm{mg} /$ day $)$, then referred to the Oral Surgery Clinic for maxillectomy, followed the fabrication of obturator prostheses by the prosthodontist team. The patient was assigned a postoperative obturator to close the palate gap after maxillectomy. An imprint was carried out using an irreversible hydrocolloid material before surgery for the manufacture of a post-surgical obturator. The obturator insertion shows that the palate gap was tightly closed by an acrylic plate. Retention was obtained using the stainless wire on titanium wire mesh instead of the maxillary bone-the patients presented no complaints during control and had adequate ingestion. Three months after wearing a postoperative obturator, the acrylic resin definitive obturator prosthesis was then installed. Clinical examination showed reduced nasal sound, and better aesthetical and mastication aspect. Conclusion: Acrylic resin definitive obturator prosthesis in post-maxillectomy SLE patients can restore aesthetic function, reduce nasal sound (restore speech function), restore swallowing and mastication function.

Keywords: Maxillectomy, acrylic resin definitive obturator prosthesis, systemic lupus erythematosus 


\section{PENDAHULUAN}

Lupus erythematosus (LE) adalah suatu penyakit autoimun yang dapat melibatkan mukosa oral sehingga memerlukan perhatian lebih dalam mempersiapkan rencana perawatan dental bagi penderita. Systemic lupus erythematosus (SLE) merupakan salah satu tipe dari LE. ${ }^{1}$ SLE merupakan penyakit autoimun kronis yang melibatkan banyak organ tubuh. Penyakit ini memiliki penjalaran penyakit yang tidak dapat diprediksi dan memiliki manifestasi penyakit yang sangat luas, dengan masa remisi dan relaps yang terjadi selama penderita menderita penyakit ini. ${ }^{2}$

Masa penularan SLE bervariasi dan dapat ditandai dengan terjadinya rekurensi inflamasi akut atau kronis dan masa remisi. Wanita lebih sering terkena dibanding pria dengan rasio rata-rata 10:1. Prevalensi SLE secara global sekitar 12 hingga 50 per 100.000 penduduk, tergantung lokasi dan etnisnya. ${ }^{3}$ Banyak dari gambaran awal SLE memiliki gambaran yang serupa dengan penyakit autoimun lainnya, namun SLE melibatkan lebih banyak sistem organ tubuh. ${ }^{2}$

Avascular bone necrosis (AVN) merupakan salah satu gejala yang muncul pada penderita SLE yang ditandai dengan kematian dari jaringan tulang karena kekurangan suplai darah. Hal ini juga disebut osteonecrosis, yang dapat menuju pada terjadinya pecahan kecil pada tulang dan jaringan tulang, sehingga tulang mati dan rapuh. Tulang yang patah atau sendi yang bergeser dapat menghalangi aliran darah ke bagian tulang tertentu. AVN juga terkait dengan penggunaan obat steroid jangka panjang dan dosis yang tinggi. ${ }^{4}$ Pada kasus ini AVN terjadi pada tulang maksila pasien yang menyebabkan fraktur horizontal bagian bawah antara maksila dan palatum/arcus alveolar komplek yang menyebabkan terpisahnya prosesus alveolaris dan palatum durum. Tindakan maksilektomi perlu dilakukan pada kasus tersebut untuk mencegah komplikasi lebih lanjut. ${ }^{3}$

Tindakan maksilektomi menyebabkan terbukanya rongga mulut, antrum, dan nasofaring. Pasca maksilektomi dapat timbul defek di palatum (rongga mulut) dan maksila yang letaknya di daerah muka sepertiga tengah (midfacial). ${ }^{5}$ Defek yang besar dapat menyebabkan morbiditas yang berhubungan dengan fungsional dan estetika. Kebanyakan defek yang terjadi dapat mengganggu fungsi secara nyata dan estetika pada kontur wajah seperti deformitas pada bibir, komplikasi orbital, gangguan bicara, dan sulit menelan, oleh karena itu defek pasca maksilektomi perlu segera dilakukan rekonstruksi. ${ }^{6}$

Celah langit-langit menyebabkan kesulitan mengunyah, bernapas dan berbicara serta mengganggu estetika dan psikologis pasien. ${ }^{6}$ Kondisi ini memerlukan perawatan konservatif dengan protesa intraoral yaitu obturator. Pembuatan obturator dapat dilakukan ketika pertumbuhan area orofasial telah sempurna, biasanya usia 15-18 tahun. Pembuatan obturator pada kasus maksilektomi radikal seperti ini merupakan perawatan yang kompleks dan jarang dilakukan. Tujuan laporan kasus ini mengkaj rehabilitasi prostetik menggunakan protesa obturator definitif resin akrilik pada penderita SLE untuk mengembalikan fungsi estetik, bicara, penelanan, dan pengunyahan pasca maksilektomi.

\section{LAPORAN KASUS}

Seorang wanita berusia 21 tahun datang ke Poli Gigi dan Mulut RSUP Dr. Sardjito dengan keluhan bau mulut, hilangnya gusi pada langitlangit, tulang pada langit-langit menghitam, dan kegoyahan gigi rahang atas. Pasien didiagnosis SLE sejak lebih dari 1 tahun yang lalu dan sedang menjalani perawatan rutin di bagian Penyakit Dalam dan bagian Bedah Plastik RSUP Dr. Sardjito Yogyakarta.

Kondisi umum pasien sedang, kesadaran compos mentis. Hasil pemeriksaan fisik pasien tekanan darah 109/78 $\mathrm{mmHg}$, pulsus $90 \mathrm{x} /$ menit, respirasi $20 \mathrm{x} /$ menit, afebris. Hasil pemeriksaan ekstraoral didapatkan moon face dan sedikit lesi pada bibir atas yang mengering (Gambar 1). Hasil pemeriksaan intraoral didapatkan defek pada jaringan lunak palatum. Tulang palatum terbuka dengan warna kehitaman dan bau sangat menyengat. Kehilangan gigi $14,15,16$, dan 25 , serta kegoyahan derajat 3 pada seluruh gigi rahang atas yang tersisa (Gambar 2).

Hasil pemeriksaan histopatologis pada tulang palatum didapatkan pertumbuhan jamur Candida pada tulang palatum yang nekrosis. Pada pemeriksaan CT Scan ditemukan atropi lobus frontotemporalis bilateral, pelebaran cavum vergae $1,99 \mathrm{~cm}$, pansinusitis, osteodestruksi pada tulang 


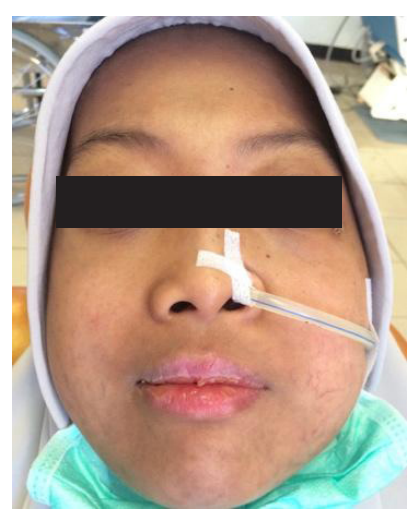

Gambar 1. Foto profil pasien yang menunjukkan moon face.(Sumber:Dokumentasi sendiri)

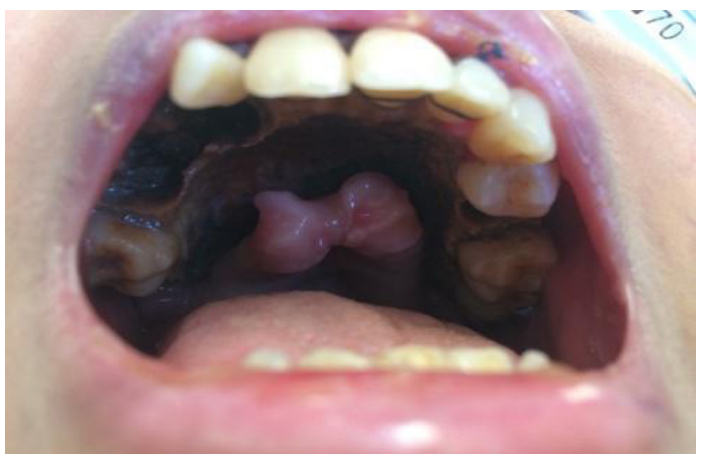

Gambar 2. Gambaran palatum terbuka berwarna kehitaman.(Sumber:Dokumentasi sendiri)

maksila bilateral, tulang zygoma bilateral, tulang frontalis dekstra, tulang temporalis bilateral, tulang sphenoidalis, dan mastoiditis dekstra. Hasil konsul ke bagian patologi anatomi menunjukkan bahwa dari hasil aspirasi jarum halus pada regio arkus palatoglosus tidak didapatkan sel ganas.

Hasil pemeriksaan sementara dapat disimpulkan bahwa pasien dicurigai menderita AVN karena SLE. AVN menyerang tulang maksila yang menyebabkan nekrosis dan terpisahnya palatum durum dan prosesus alveolaris. Pasien dikonsulkan ke poli bedah mulut dan tim prostodonti untuk operasi pengangkatan maksila dan pembuatan obturator pasca maksilektomi. Pembuatan obturator pada kasus maksilektomi radikal seperti pada kasus ini merupakan perawatan yang sulit dan jarang dilakukan.

Tindakan pertama yang dilakukan adalah melakukan pencetakan model kerja untuk pembuatan obturator pasca bedah. Pencetakan dengan menggunakan bahan hydrocolloid irreversible dan diisi dengan menggunakan gips stone. Dibuat desain operasi dengan penghilangan gigi dan palatum pada model kerja (Gambar 3). Pembuatan obturator pasca bedah menggunakan

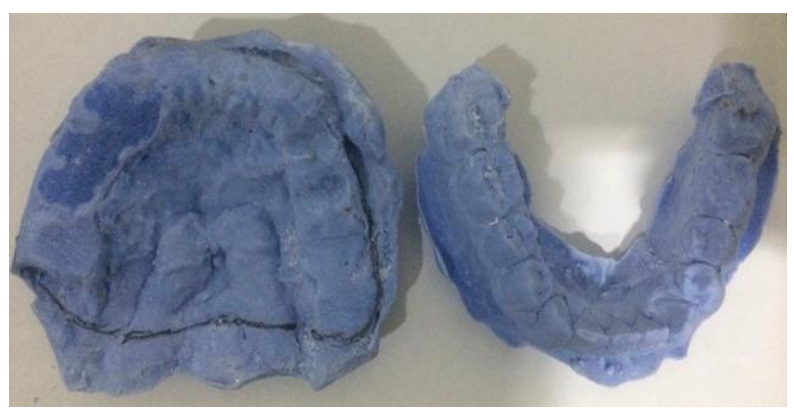

Gambar 3. Gambar desain obturator pasca bedah rahang atas setelah simulasi penghilangan gigi dan palatum.

(Sumber:Dokumentasi sendiri)

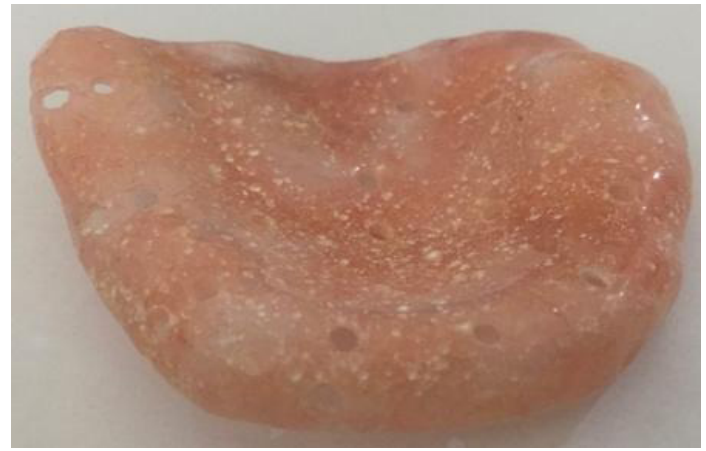

Gambar 4. Obturator pasca bedah berbahan resin akrilik dengan campuran Nystatin dan penambahan lubang untuk retensi.(Sumber:Dokumentasi sendiri)

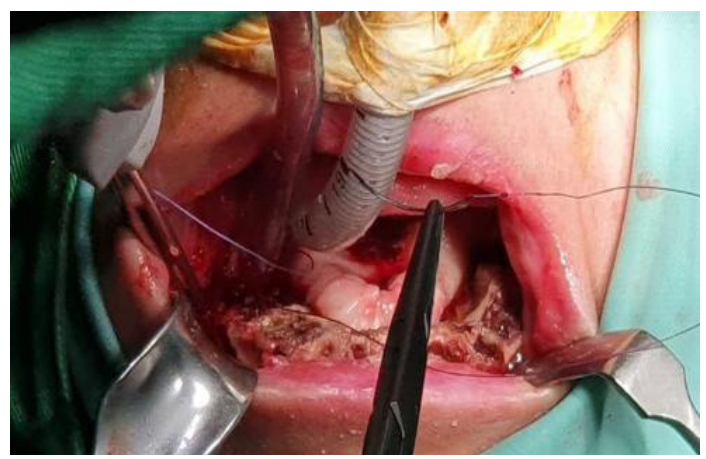

Gambar 5. Proses operasi maksilektomi.

(Sumber:Dokumentasi sendiri)

bahan resin akrilik dengan pencampuran serbuk Nystatin 1:500.000 IU pada polimer resin akrilik. Pada permukaan obturator dibuat lubang-lubang untuk retensi (Gambar 4).

Tindakan debridement dilakukan secara menyeluruh pada lesi dengan anestesi umum. Maksilektomi dilakukan pada seluruh tulang palatum yang mengalami nekrosis dan dipastikan tidak ada jaringan nekrotik yang tertinggal (Gambar 5). Potongan jaringan nekrotik ditampung ke dalam pot formalin untuk dilakukan pemeriksaan patologi anatomi (Gambar 6). Titanium wire mesh dibentuk dan dipotong sesuai dengan tulang maksila yang 


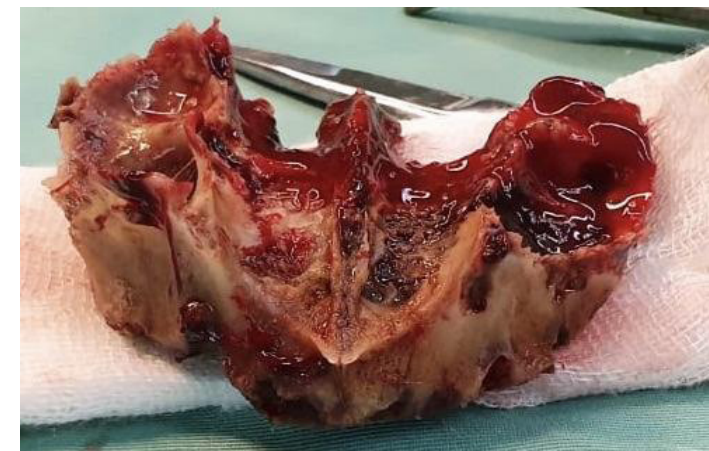

Gambar 6. Tulang maksila nekrosis yang diambil dan dilakukan pemeriksaan patologi anatomi lebih lanjut. (Sumber:Dokumentasi sendiri)

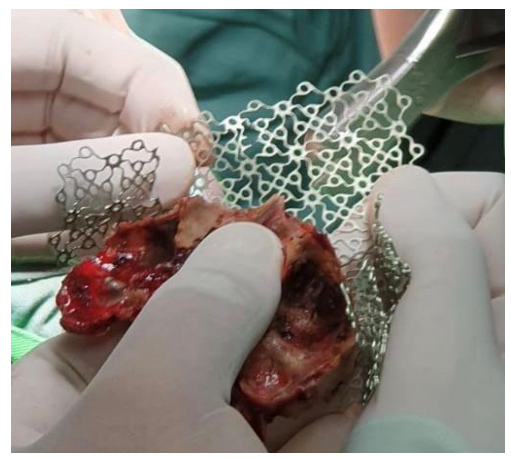

Gambar 7. Titanium wire mesh dibentuk dan dipotong sesuai dengan ukuran tulang maksila yang diambil. (Sumber:Dokumentasi sendiri)

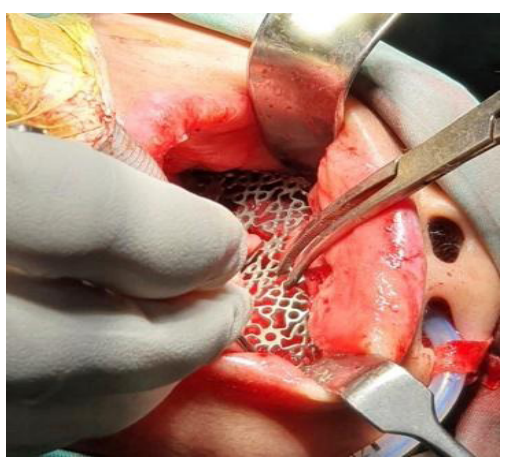

Gambar 8. Pemasangan titanium wire mesh menggantikan tulang maksila dan palatum.(Sumber:Dokumentasi sendiri)

diambil (Gambar 7), kemudian dipasangkan pada defek maksila dan dilakukan pemasangan sekrup di tulang zygomatikum sebagai retensi titanium wire mesh (Gambar 8). Pencetakan palatum yang terbuat dari titanium wire mesh dilakukan dengan sendok cetak sediaan nomor 2 dengan bahan cetak hydrophilic vinyl polysiloxane dengan separator kasa (Gambar 9). Cetakan negatif diisi dengan gips stone untuk persiapan pembuatan obturator definitif.

Obturator pasca bedah dipasang dengan mengikatkan lubang pada protesa pada lubang titanium wire mesh dengan menggunakan kawat

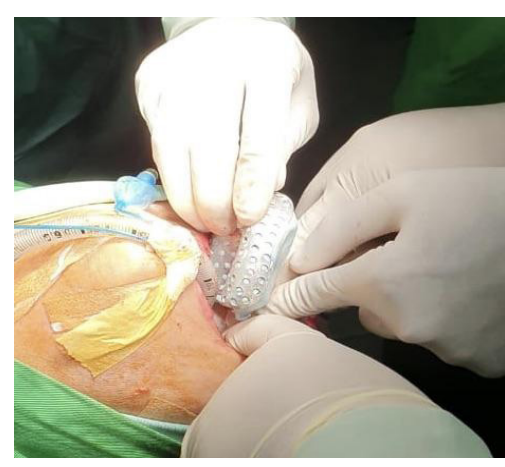

Gambar 9. Pencetakan rahang atas yang terbuat dari titanium wire mesh dengan bahan cetak silikon.

(Sumber:Dokumentasi sendiri)

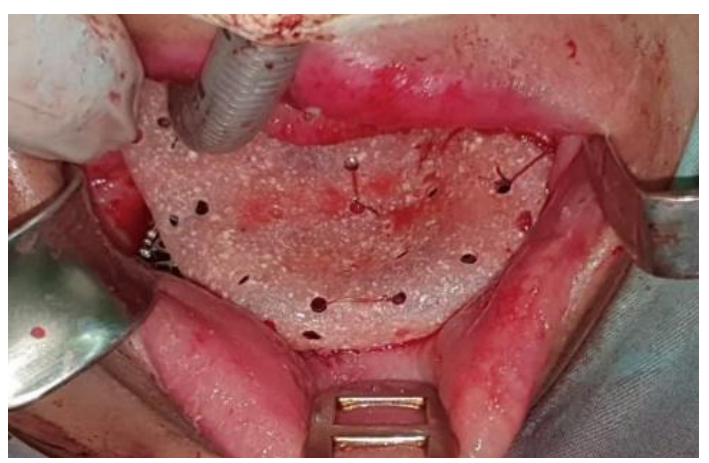

Gambar 10. Foto pemasangan protesa obturator pasca bedah dengan bantuan kawat stainless.

(Sumber:Dokumentasi sendiri)

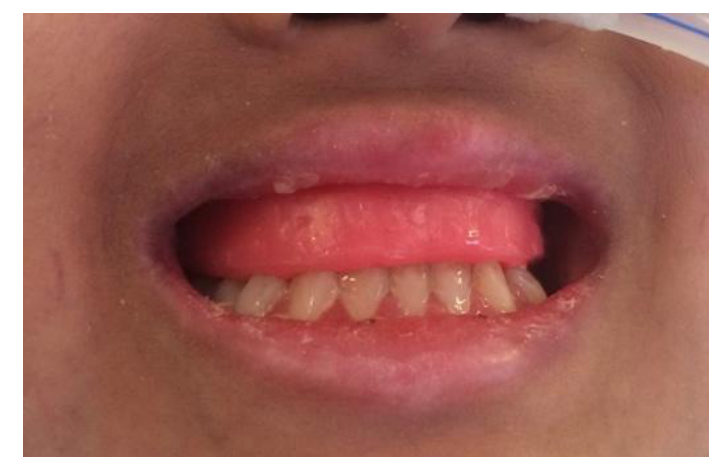

Gambar 11. Pengukuran vertikal dimensi dan pencatatan relasi sentrik. (Sumber:Dokumentasi sendiri)

stainless di beberapa tempat untuk meningkatkan retensi obturator (Gambar 10). Nasogastric tube dipasang untuk menjaga kecukupan asupan nutrisi dan memastikan area luka operasi tidak terkontaminasi sisa makanan untuk sementara.

Perawatan pasca operasi, pasien mendapatkan terapi peroral yang sama dengan sebelum tindakan operasi yaitu Myfortic (2x 180 $\mathrm{mg} /$ hari) dan Fluconazole (1×150 mg/hari). Kontrol dilakukan dua minggu pasca operasi untuk melihat kondisi jaringan rongga mulut dan kebersihan obturator pasca bedah. 


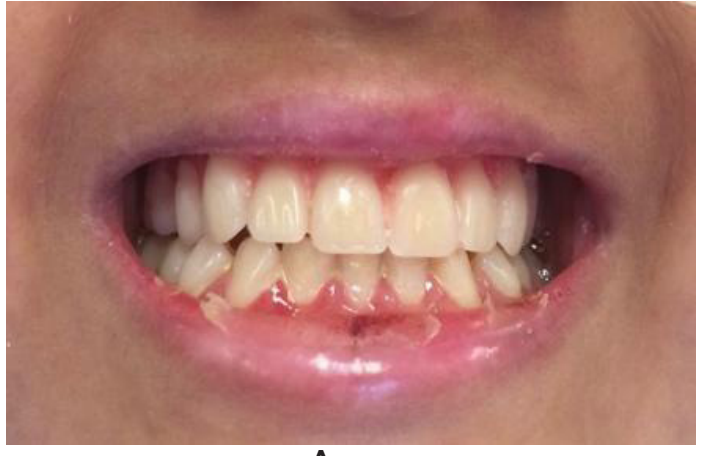

A

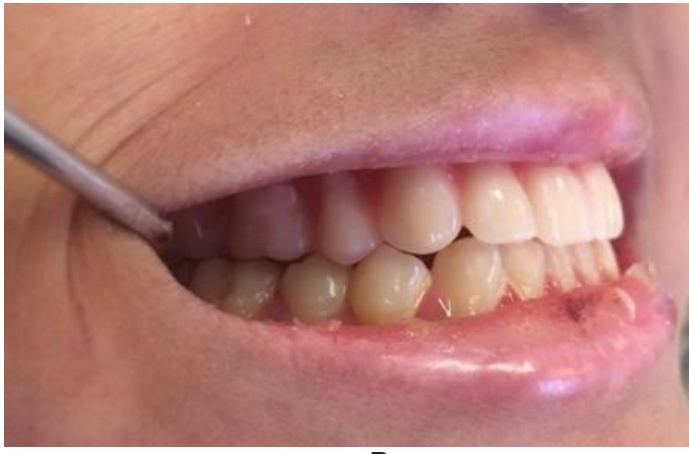

B

Gambar 12. Try in obturator definitif dilihat dari depan (A) dan dari samping (B). (Sumber:Dokumentasi sendiri)

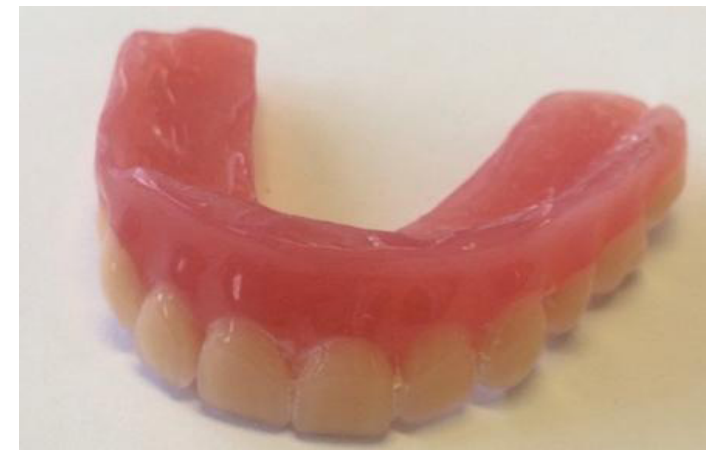

Gambar 13. Prosesing akhir obturator definitif dengan menggunakan resin akrilik kuring panas. (Sumber:Dokumentasi sendiri)

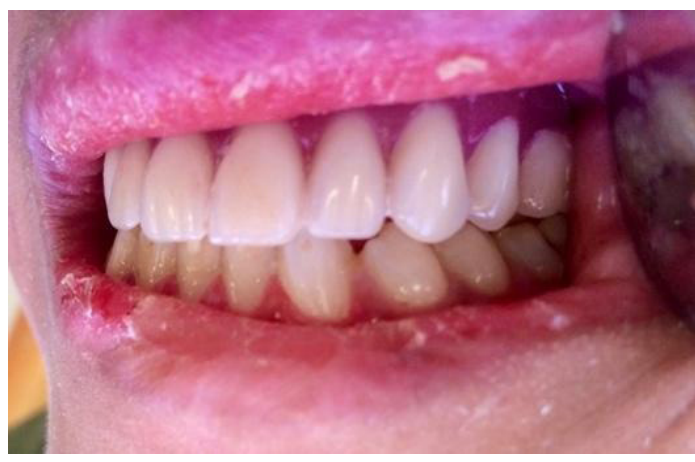

Gambar 14. Insersi obturator definitive resin akrilik. (Sumber:Dokumentasi sendiri)

Tiga bulan pasca pemasangan obturator pasca bedah, mulai dilakukan pembuatan obturator definitif berdasarkan cetakan model kerja yang didapatkan pada saat operasi. Diawali dengan pembuatan base plate dari malam merah yang diproses menggunakan resin akrilik kuring panas. Dilanjutkan dengan pemasangan bite rim (Gambar 11) dan mencari vertikal dimensi dengan metode Willys dimana jarak pupil ke sudut mulut sama dengan jarak hidung ke dagu dikurangi $2 \mathrm{~mm}$ sebagai free way space dalam keadaan oklusi. Untuk mencari sentrik relasi dan fiksasi, ditambahkan 1 lembar malam lunak pada permukaan bite rim kemudian pasien diminta untuk menggigit hingga gigi-gigi rahang bawah masuk pada lapisan malam bite rim rahang atas. Cetakan rahang bawah menggunakan cetakan awal sebelum operasi. Mounting pada artikulator dilanjutkan pemasangan gigi-gigi artifisial rahang atas.

Try in pada pasien dilakukan untuk melihat profil dan oklusi (Gambar 12). Prosesing akhir menggunakan bahan resin akrilik kuring panas (Gambar 13). Insersi obturator definitif menggunakan kawat stainless yang mengikat lubang-lubang pada base plate obturator dengan lubang pada titanium wire mesh. Pemeriksaan klinis pada saat insersi menunjukkan suara sengau berkurang, estetis, dan pengunyahan baik (Gambar 14). Tiga bulan pasca pemasangan obturator definitif dilakukan kontrol untuk melihat pertumbuhan jaringan lunak pada titanium wire mesh dan membersihkan obturator definitif. Tidak ada keluhan pada saat kontrol obturator definitif. Pasien menyetujui kasusnya untuk dipublikasikan dengan menandatangani informed consent.

\section{PEMBAHASAN}

Systemic lupus erythematosus (SLE) adalah suatu penyakit autoimun multisistemik yang ditandai dengan munculnya inflamasi kronis. ${ }^{2}$ Daerah yang menjadi target kerusakannya adalah jaringan dan organ tubuh seperti kulit, persendian, membran serosa dan sistem persarafan. ${ }^{1}$ Pada kasus ini kerusakan pada rongga mulut muncul setelah 1 tahun pasien terdiagnosis SLE. Gejala yang muncul berupa kerusakan jaringan keras maksila.

Etiologi SLE masih belum dapat dimengerti secara menyeluruh, namun diduga terdapat 
keterlibatan genetis dan lingkungan. SLE dikarakterisasikan dari adanya hiperaktivitas sel $B$, yang menghasilkan produksi IgG dan kompleks imun. Sejumlah antibodi tertentu (auto antibodi) menyebabkan kerusakan seluler dalam bentuk reaksi hipersensitivitas tipe II atau dengan berpartisipasi membentuk kompleks imun. Hal ini menyebabkan terbentuknya deposit pada jaringan dan organ sehingga terjadi kerusakan jaringan. ${ }^{1}$

Pasien yang kerusakan yang terjadi berupa nekrosis tulang maksila dan pertumbuhan jamur Candida. Avascular bone necrosis (AVN) merupakan salah satu gejala yang muncul pada penderita SLE. ${ }^{4}$ Dikenal juga dengan istilah osteonecrosis dimana kondisi jaringan tulang yang mati karena kekurangan pasokan darah. Pada tahap awal AVN umumnya tidak menunjukkan gejala, namun seiring waktu, tulang yang terpengaruh akan terasa nyeri. AVN juga terkait dengan penggunaan obat steroid jangka panjang dan dosis yang tinggi. ${ }^{3}$ Kasus ini AVN terjadi pada tulang maksila pasien yang menyebabkan fraktur horizontal bagian bawah antara maksila dan palatum/arcus alveolar komplek yang menyebabkan terpisahnya prosesus alveolaris dan palatum durum. Hasil biopsi menunjukkan adanya superinfeksi jamur berupa Candida. Hal ini yang membuat kondisi rongga mulut menjadi sangat bau. Perawatan maksilektomi perlu dilakukan pada kasus tersebut untuk mencegah komplikasi lebih lanjut. $^{3}$

Maksilektomi merupakan tindakan pengangkatan maksila secara pembedahan, sering disebut juga dengan reseksi maksila. ${ }^{5}$ Maksilektomi merupakan suatu tindakan pada maksila yang menimbulkan defek pada wajah dan rongga mulut berupa kerusakan dan perubahan bentuk pada wajah serta fungsi oral. Rekonstruksi maksila adalah rehabilitasi perawatan pada defek maksila setelah dilakukan tindakan pembedahan yang melibatkan hilangnya sebagian atau seluruh maksila. ${ }^{6,7}$

Kasus ini defek pasca maksilektomi ditutup dengan protesa intraoral beruba obturator pasca bedah yang terbuat dari resin akrilik guna mencegah masuknya makanan dalam saluran pernafasan. ${ }^{8}$ Pada kasus ini polimer resin akrilik sebagai bahan pembuat obturator dicampur dengan serbuk Nystatin dengan harapan mampu menekan pertumbuhan jamur pada area operasi. Penambahan obat anti jamur pada saat pencampuran serbuk dan cairan basis resin akrilik pada gigi tiruan bertujuan agar obat anti jamur bisa bekerja langsung, meminimalisir konsumsi obat sistemik, menghemat ekonomi dalam pembelian obat secara berulang, dan menghindari efek samping dari mengkonsumsi obat anti jamur tersebut. ${ }^{9}$ Pemberian Nystatin dilakukan agar tidak muncul infeksi kembali. Nystatin termasuk obat yang efektif dalam mengatasi infeksi jamur. ${ }^{10}$

Rekonstruksi defek pasca maksilektomi harus dilakukan mengingat apabila dibiarkan akan mengakibatkan morbiditas yang tinggi, yaitu gangguan yang hebat pada fungsi (menelan, bicara) dan kosmetik. ${ }^{6}$ Tujuan dari rekonstruksi defek maksila yaitu mempertahankan jalan makanan (maintain alimentation), mempertahankan fungsi bicara (restore speech), mempertahankan bentuk pipi dan bibir (provide lip and cheek support) dan mempertahankan bentuk muka (re-establish midface projection). ${ }^{11}$

Tulang maksila yang telah diambil kemudian digantikan dengan titanium wiremesh sebagai pengganti palatum. Retensi dari palatum tiruan diperoleh melalui sekrup yang dipasang pada tulang zigomatikum. Retensi antara obturator dengan titanium wire mesh diperoleh melalui ikatan dengan kawat stainless. Seringkali untuk menahan obturator pada tempatnya dilakukan fiksasi ke sisa tulang atau gigi dengan sekrup atau kawat. Secara periodik, sekrup atau ikatan kawat ini dapat dilepas untuk melakukan pembersihan rongga maksila-hidung-nasofaring (irigasi) dan pencucian obturator. ${ }^{6}$

Kontrol obturator pasca bedah dilakukan 2 minggu setelah operasi guna menjaga kebersihan dan melihat pertumbuhan jaringan. Pasien harus menjaga kebersihan baik daerah luka operasi dan protesa. Oral hygiene yang buruk pada pemakai obturator dapat menyebabkan pembentukan krusta, bau busuk, dan regurgitasi oronasal. Beberapa kelemahan ini menyebabkan pasien akan mengalami penurunan kualitas hidup..$^{12}$

Penatalaksanaan pasca maksilektomi dan pemasangan obturator pada umumnya meliputi pemberian obat yang adekuat. ${ }^{10}$ Pemberian imunosupresan dan anti jamur yang adekuat sesuai dengan hasil kultur juga berperan penting dalam kesembuhan penyakit ini. Terapi imunosupresan Myfortic dan anti jamur Fluconazole merupakan 
kombinasi yang disarankan. Pemasangan nasogastric tube sangat dianjurkan untuk menjaga asupan nutrisi dan memastikan kebersihan area mulut dari sisa makanan. ${ }^{7}$ Penderita dianjurkan diet makanan lunak sampai fungsi pencernaannya kembali normal. Setelah luka operasi sembuh (3-6 bulan), prostodontis akan membuat modifikasi obturator disertai deretan gigi yang mirip dengan gigi palsu (obturator definitif). ${ }^{7,8}$

Obturator definitif pada kasus ini dibuat setelah pasien 3 bulan memakai obturator pasca bedah. Fungsinya untuk mengembalikan fungsi fonetik, estetik, dan pengunyahan pasien. Pembuatan obturator definitif pada kasus total edentulous dilakukan sama halnya dengan pembuatan gigi tiruan lengkap dimana dibutuhkan pengukuran vertikal dimensi dan penetapan oklusi sentrik. ${ }^{13}$ Penentuan vertikal dimensi dan relasi sentrik yang tepat akan mempengaruhi kualitas mastikasi pasien.

Sebelum dilakukan insersi obturator definitif perlu dilakukan try in terlebih dahulu agar plat gigi tiruan tidak menimbulkan tekanan, iritasi ataupun rasa sakit pada defek. ${ }^{13}$ Sama halnya dengan obturator pasca bedah, retensi pada obturator definitif ini didapatkan melalui ikatan kawat stainless antara baseplate dengan titanium wire mesh. Evaluasi pasien setelah menggunakan protesa obturator definitif resin akrilik menunjukkan adanya perbaikan fungsi fonetik, estetik, pengunyahan, serta penelanan. Penggunaan obturator dapat meningkatkan fungsi estetik, fonetik dan mastikasi pasien. Penggunaan obturator pada kasus celah langit-langit memberikan peningkatan fungsi fonetik pasien karena suara sengau pasien berkurang dan

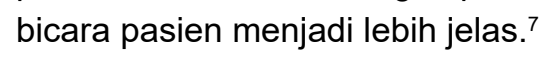

\section{SIMPULAN}

Protesa obturator definitif resin akrilik pada pasien SLE pasca maksilektomi dapat mengembalikan fungsi estetik, mengurangi suara sengau (mengembalikan fungsi bicara), mengembalikan fungsi penelanan, dan pengunyahan.

\section{DAFTAR PUSTAKA}

1. Bertsias G, Cervera R, Boumpas DT. Systemic Lupus Erythematosus: Pathogenesis and
Clinical Features. EULAR Textbook on Rheumatic Diseases. 2th ed. United Kingdom: BMJ: 2012. h. 476-505.

2. Aleem A, Saud A, Arfaj A, Alarfaj $H$. Haematological abnormalities in Systemic Lupus Erythematosus. ACTA Reum PORT. 2014; 39(3): 236-241.

3. Albilia JB, Lam DK, Clokie CM, Sándor GK. Systemic lupus erythematosus: a review for dentists. J Can Dent Assoc. 2010; 73(9): 823-8.

4. Uva L, Miguel D, Pinheiro $C$, Freitas $P$, Gomes MM, Filipe P. Cutaneous Manifestations of Systemic Lupus Erythematosus. Autoimmune Diseases. Hindawi. 2012. h.1-15. DOI: 10.1155/2012/834291

5. lyer S, Thankappan K. Maxillary reconstruction: Current concepts and controversies. Indian J Plast Surg. 2014; 47(1): 8-19. DOI: 10.4103/0970-0358.129618.

6. Andrades $\mathrm{P}$, Militsakh $\mathrm{O}$, Hanasono MM, Rieger J, Rosenthal EL. Current strategies in reconstruction of maxillectomy defects. Arch Otolaryngol Head Neck Surg. 2011; 137(8): 806-12. DOI: 10.1001/archoto.2011.132.

7. Cooper HK. Cleft palate and cleft lip: A team approach to clinical management and rehabilitation of the patient. Toronto: WB Saunders Co.; 1979: h. 176. DOI: 10.1002/ hed.2890030212

8. Taylor, Thomas D. Clinical Maxillofacial Prosthetics. $1^{\text {st }}$ ed. Illinois: Quintessence Publishing Co., Inc: 2006. h. 113.

9. Salim N, Moore C, Silikas N, Satterthwaite JD, Rautemaa R. Fungicidal amounts of antifungals are released from impregnated denture lining material for up to 28 days. J Dent. 2012; 40(6): 506-12. DOI: 10.1016/i.jdent.2012.02.016.

10. Weinstein L. Superinfection. A complication of antimicrobial therapy and prophylaxis. Am J Surg 1964:107(5):704-709. DOI: 10.1016/0002-9610(64)90297-1.

11. Santamaria E, Cordeiro PG. Reconstruction of maxillectomy and midfacial defects with free tissue transfer. J Surg Oncol. 2006; 94(6): 52231. DOI: $10.1002 / \mathrm{jso} .20490$.

12. Araf KAO. Comparing the Retention between two types of obturator constricted from Heat Cure Acrylic Resin, and Flexible Resin. Life Sci J. 2014; 11(8): 694-697

13. Montero J, Macedo C, Rodriguez M, López- 
Valverde A, de Diego RG, Albaladejo A, Del Castillo R, Maroto J. Case report prosthetic rehabilitation of an edentulous cleft palate using a denture with a palatal obturator: a clinical report. J Clin Exp Dent. 2011; 3(1): 36570. DOI: $10.4317 /$ jced.3.e365 